\title{
Nanoparticles in boreal forest and coastal environment: a comparison of observations and implications of the nucleation mechanism
}

\author{
K. Lehtipalo ${ }^{1}$, M. Kulmala ${ }^{1}$, M. Sipilä ${ }^{1,2}$, T. Petäjä ${ }^{1}$, M. Vana ${ }^{1,3}$, D. Ceburnis ${ }^{4}$, R. Dupuy ${ }^{4, *}$, and C. O'Dowd ${ }^{4}$ \\ ${ }^{1}$ Department of Physics, University of Helsinki, P.O. Box 64, 00014, Helsinki, Finland \\ ${ }^{2}$ Helsinki Institute of Physics, University of Helsinki, P.O. Box 64, 00014, Helsinki, Finland \\ ${ }^{3}$ Institute of Physics, University of Tartu, Ülikooli 18, 50090 Tartu, Estonia \\ ${ }^{4}$ School of Physics \& Centre for Climate and Air Pollution Studies, Environmental Change Institute, \\ National University of Ireland Galway, Galway, Ireland \\ * currently at: Université Blaise Pascal, INSU, UMR6016, Laboratoire de Météorologie Physique, 63177 Aubiere, France
}

Received: 23 November 2009 - Published in Atmos. Chem. Phys. Discuss.: 11 December 2009

Revised: 7 July 2010 - Accepted: 18 July 2010 - Published: 2 August 2010

\begin{abstract}
The detailed mechanism of secondary new particle formation in the atmosphere is still under debate. It is proposed that particle formation happens via activation of 1-2 nm atmospheric neutral molecular clusters and/or large molecules. Since traditional instrumentation does not reach these sizes, the hypothesis has not yet been verified. By directly measuring particle size distributions down to mobility diameters of about $1.3 \mathrm{~nm}$ with a pulse-height CPC, we provide evidence of the nucleation mechanism in a coastal environment (Mace Head, Ireland) and in a boreal forest (Hyytiälä, Finland). In both places neutral sub-3 nm condensation nuclei (nano-CN) were continuously present, even when no new particle formation was detected. In Mace Head, however, the concentration of the nano-CN was far too low to account for the particle formation rates during particle bursts. Thus the results imply that at coastal sites new particle formation initiates, as previously proposed, via homogenous nucleation from biogenic iodine vapors. In contrast, activation of pre-existing nano- $\mathrm{CN}$ remains a possible explanation in the boreal forest, but the observed concentrations are not the limiting factor for the particle formation events.
\end{abstract}

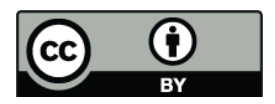

Correspondence to: K. Lehtipalo (katrianne.lehtipalo@ helsinki.fi)

\section{Introduction}

Aerosol particles deteriorate air quality, atmospheric visibility and human health. Additionally, particles affect the climate both directly by scattering and absorbing solar radiation, and indirectly via cloud processes. Atmospheric aerosols have both natural and anthropogenic sources. New particle formation by gas-to-particle conversion has been frequently observed around the world (Kulmala et al., 2004). Condensational growth in the atmosphere can make the newly formed particles large enough to act as cloud condensation nuclei (e.g. O'Dowd, 2001; Laaksonen et al., 2005). According to model simulations, these particle formation events affect the particle budget significantly both on regional and global scale (Spracklen et al., 2006). Nevertheless, the IPCC (Intergovernmental Panel on Climate Change) assigns the biggest uncertainty ranges in the radiative forcing estimates to aerosols (IPCC, 2007). Hence, molecular level understanding of nucleation is needed to incorporate the secondary particle formation into the climate models.

Particles can nucleate homogeneously from one or several precursor vapors if the vapor concentrations are high enough. In general, lower supersaturations are needed when particles form heterogeneously on a pre-existing surface (e.g. Kulmala et al., 2007b). Heterogeneous nucleation on a 1-2 nm molecular cluster, also known as activation of clusters, is proposed

Published by Copernicus Publications on behalf of the European Geosciences Union. 
as an explanation for particle formation events (Kulmala et al., 2000, 2006). Charged cluster ions are known to exist in the atmosphere (e.g. Hõrrak et al., 1998), and their recombination could produce electrically neutral particles (Turco et al., 1998). Nucleation on a charged cluster is called ion induced nucleation (Yu and Turco, 2000), and the vapor concentrations required for activation of ions are lower than for neutral particles (Winkler et al., 2008). There is no consensus on how large a share of atmospheric new particle formation is ion-induced or ion-mediated. Some studies have underlined the crucial role of ions (Yu et al., 2008; Yu and Turco, 2008), whereas the conclusions of several other experiments show that the ion concentrations are too low to explain the observed particle formation rates in the boundary layer (e.g. Laakso et al., 2004; Iida et al., 2006; Gagné et al., 2008; Kulmala et al., 2007a).

Different particle formation mechanisms might be prevailing in different environmental conditions. Here we compare measurements from two very distinct environments: the boreal forest in Hyytiälä, southern Finland, and the coast of the North Atlantic Ocean, in Mace Head, Ireland. In Hyytiälä, new particle formation is observed on about $25 \%$ of days, most frequently in spring time (Dal Maso et al., 2005). However, particles grow the fastest in the summer indicating that particle formation and growth are two separate processes (Hirsikko et al., 2005). In Mace Head, strong particle formation bursts are frequently observed in daytime during low tide, probably due to biogenic emission of iodine vapors (O’Dowd et al., 2002c; Yoon et al., 2006). Several laboratory experiments have demonstrated particle formation from the oxidation products of these iodine-compounds (Hoffmann et al., 2001; Jimenez et al., 2003).

A reason for the lack of knowledge about the nucleation process has been the incapability to detect or chemically identify the initial clusters. Recent development of measurement techniques (e.g. Mirme et al., 2007; Sipilä et al., 2009) has provided us with tools to reach molecular sizes. Already Weber et al. (1995) detected molecular clusters when ultrafine particles were present. Continuous existence of a neutral cluster pool below $3 \mathrm{~nm}$ was first discovered in Hyytiälä by Kulmala et al. (2007a). The applicability of condensation particle counters (CPCs) to detect clusters was further studied by Sipilä et al. (2008). However, CPC measurements alone can not determine if the activated nanometer-size condensation nuclei (nano-CN) are nucleated particles, molecular clusters or large molecules. In many previous articles, they were simply called clusters.

In this article we look for similarities and differences in the characteristics of nano-CN concentrations between boreal forest and coastal environments. Since an analysis of the nano-CN in Hyytiälä has already been published by Lehtipalo et al. (2009), the focus here will be on describing the first nano-CN measurements in Mace Head using a pulse-height CPC. We compare the concentrations measured with different instruments to theoretical calculations and to each other.
Thus we aim at resolving the possible nucleation mechanism and estimating the importance of clusters to new particle formation at both sites.

\section{Materials and methods}

\subsection{Site description}

Hyytiälä SMEAR II - station $\left(61^{\circ} 51^{\prime} \mathrm{N}, 24^{\circ} 17^{\prime} \mathrm{E}\right)$ is situated in southern Finland about $60 \mathrm{~km}$ north-east from the city of Tampere. The nearest village with some industrial activity is circa $10 \mathrm{~km}$ away, and the nearest buildings are by a small lake $500 \mathrm{~m}$ away from the measurement station. The station is surrounded by a coniferous Scots pine dominated forest. All the measurements discussed in this article were done inside the forest canopy. The station is equipped with extensive meteorological and aerosol instrumentation. For a more detailed site description see Hari and Kulmala (2005).

The Mace Head atmospheric research station $\left(54^{\circ} 19^{\prime} \mathrm{N}\right.$, $9^{\circ} 54^{\prime} \mathrm{W}$ ) is a GAW (Global Atmosphere Watch) super-site situated on the west coast of Ireland facing the North Atlantic ocean. The station is located $100 \mathrm{~m}$ from the coastline and surrounded by bare land (rocks, grass and peat bog) with no forest or trees. Few scattered single houses are located at a distance of $1 \mathrm{~km}$ or greater. The nearest city (Galway, 80000 inhabitants) is located $60 \mathrm{~km}$ to the east/south-east of the station. The site is well exposed to clean marine westerly air masses associated with low pressure systems accounting for nearly $50 \%$ of occurrences. Pollution outbreaks are related to high pressure synoptic scale conditions bringing polluted air from the UK and continental Europe.

\subsection{Instruments and measurements}

Particle size distribution from $\sim 1.3 \mathrm{~nm}$ to $5 \mathrm{~nm}$ in mobility diameter was measured in Hyytiälä 1-31 May 2008 and in Mace Head 13 June-25 August 2008 by applying pulseheight analysis method (e.g. Saros et al., 1996) to a condensation particle counter (CPC). The pulse height analysis method has formerly been used in size distribution measurements between 3 and $10 \mathrm{~nm}$ (Weber et al., 1995), as well as to determine the composition of freshly nucleated nanoparticles (O’Dowd et al., 2002a).

The pulse-height CPC (PH-CPC) consists of a TSI 3025 CPC with modified optics (Dick et al., 2000) and a multichannel analyzer. The temperature difference between the CPC condenser and saturator was increased until homogenous nucleation of condensing liquid, n-butanol, occurred. The pulse-height analysis method allows distinction between activation of nano-CN and homogenous nucleation (Sipilä et al., 2008). Every other measurement was made through a diffusion tube, which enabled subtraction of the pulses from homogenous nucleation. Ions were filtered away by applying a voltage to an ion trap. The PH-CPC is capable of detecting particles down to $\sim 1.3 \mathrm{~nm}$ in mobility diameter with a 


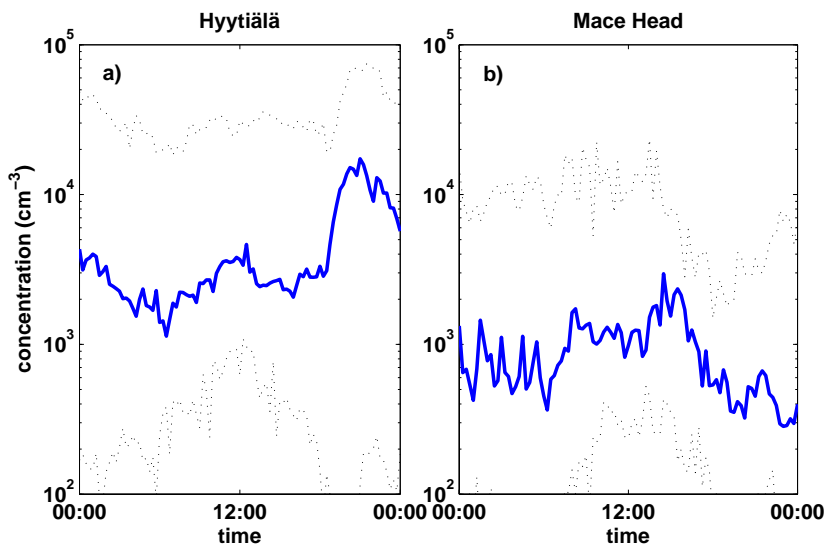

Fig. 1. Diurnal variation of nano-CN $(1.3-3 \mathrm{~nm})$ concentration in Hyytiälä and Mace Head. The solid line is at the median of $15 \mathrm{~min}$ mean concentrations during the whole measurement period, and the dashed lines indicate 5\%- and 95\%-percentiles.

detection efficiency of a few percent (Sipilä et al., 2008), but the exact size scale and detection efficiency depends on particle composition, charge and background aerosol concentration (O’Dowd, 2004; Sipilä et al., 2009). The data inversion to resolve particle size distribution between 1.3 and $5 \mathrm{~nm}$ is based on experimental calibrations with positive silver and Am241-charger generated ions. A detailed description of performance of the instrument and data inversion is presented in Sipilä et al. (2009).

The ambient ion size distribution was measured in Hyytiälä with a Balanced Scanning Mobility Analyzer (BSMA; Tammet et al., 2006), and in Mace Head with a Neutral Cluster and Air Ion Spectrometer (NAIS; Mirme et al., 2007; Manninen et al., 2009b). The mobility range of the BSMA is $0.032-3.2 \mathrm{~cm}^{2} \mathrm{~V}^{-1} \mathrm{~s}^{-1}$ (corresponding to $\sim 0.8-7.5 \mathrm{~nm}$ in mobility diameter), and the NAIS 0.0013 $3.2 \mathrm{~cm}^{2} \mathrm{~V}^{-1} \mathrm{~s}^{-1}(\sim 0.8-40 \mathrm{~nm})$. The NAIS has two operation modes: one for naturally charged ions, and one for neutral particles, which are charged by a corona charger before mobility classification. The charging sets the lower detection limit for neutral particles to about $2 \mathrm{~nm}$ depending on polarity and concentration (Asmi et al., 2009). Aerosol size distribution between 3 and $500 \mathrm{~nm}$ was measured using a twinDMPS (Aalto et al., 2001) in Hyytiälä and a Scanning Mobility Particle Sizer (SMPS) in Mace Head.

\subsection{Data analysis}

For the air mass analysis, $24 \mathrm{~h}$ back-trajectories were calculated with the HYSPLIT model (Draxler and Rolph, 2003) at Mace Head at $500 \mathrm{~m}$ altitude. Based on the trajectories, the data set from Mace Head was divided into air masses coming directly from the ocean from south to north-west sector (as the sector I in O'Dowd et al., 2002b) representing clean marine air, and into air masses that had been over land area for the past $24 \mathrm{~h}$ (coming from any other direction).

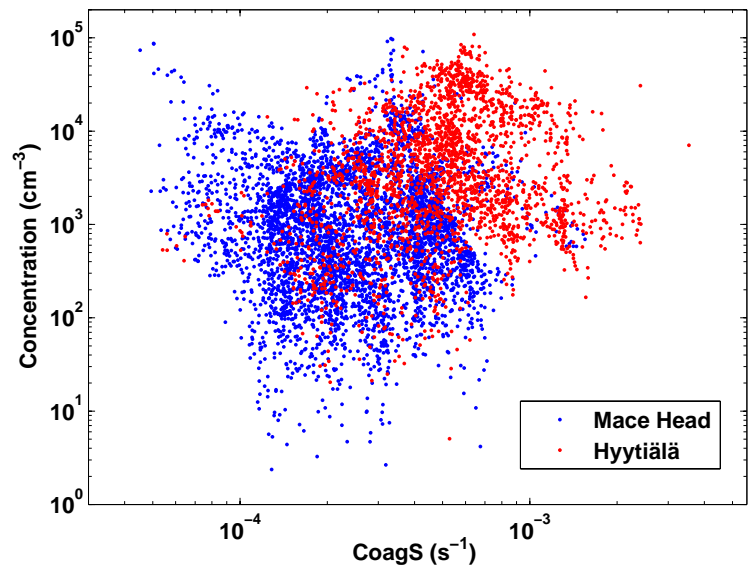

Fig. 2. The measured nano-CN concentration as a function of the coagulation sink (CoagS) calculated for $2 \mathrm{~nm}$ particles from DMPS/SMPS data.

Neutral particles can be formed in collisions of ions of the opposite charges. We wanted to estimate the contribution of the recombination products to the nano- $\mathrm{CN}$ concentration at the two sites. A maximum estimate for the steady-state concentration of the recombination products was calculated from

$N_{\mathrm{n}, \text { rec }}=\frac{\gamma \alpha N_{\mathrm{i}}^{+} N_{\mathrm{i}}^{-}}{\operatorname{CoagS}\left(N_{\mathrm{n}, \text { rec }}\right)}$

where the subscript $\mathrm{n}$ refers to neutral clusters and $\mathrm{i}$ to ion clusters, while $\gamma$ is the fraction of stable recombination products and $\alpha$ the ion-ion recombination coefficient. For $\alpha$ we used a value of $1.6 \times 10^{-6} \mathrm{~cm}^{3} \mathrm{~s}^{-1}$ (Tammet and Kulmala, 2005), and to obtain a maximum estimate, $\gamma$ was set to unity. The ion cluster concentrations were taken from ion spectrometer data so that only collisions between ions large enough to produce particles about $1.5-3 \mathrm{~nm}$ in diameter were accounted for. The coagulation sink (CoagS) was calculated for $2 \mathrm{~nm}$ particles from DMPS/SMPS data as in e.g. Dal Maso et al. (2002).

\section{Results}

\subsection{Concentrations}

Measurements with a pulse-height CPC were performed at Hyytiälä in May 2008 and at Mace Head in summer 2008 as a part of the EUCAARI campaign (Kulmala et al., 2009). Hereafter we refer as nano-CN concentration to the sum of neutral particles smaller than $3 \mathrm{~nm}$ in mobility diameter measured with the PH-CPC. At Hyytiälä, the concentration of nano-CN was mostly on the order of $10^{3} \mathrm{~cm}^{-3}$, sometimes reaching tens of thousands of particles $\mathrm{cm}^{-3}$ (Fig. 1a). The highest concentrations were often measured shortly after sunset. A nighttime maximum was observed on 20 of 30 days 


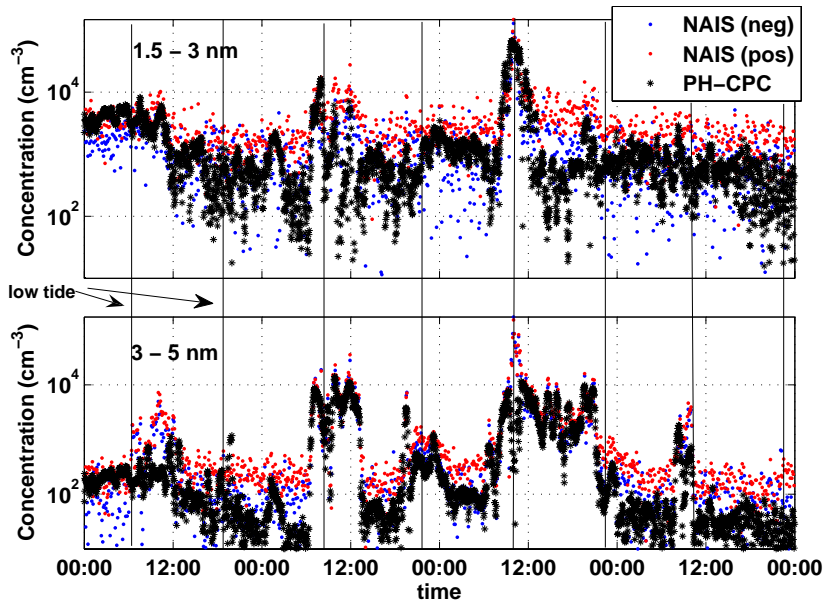

Fig. 3. Total concentration of $1.5-3 \mathrm{~nm}$ and $3-5 \mathrm{~nm}$ particles in Mace Head 13-16 June 2008 measured with the PH-CPC (black dots) and the NAIS (red and blue dots for positive and negative charging polarity of the instrument). Vertical lines indicate the times of low tide.

in May, and the cluster ion concentration and mean size grew simultaneously. No growth to larger sizes was, however, observed during the nighttime. The average diurnal behavior of the nano-CN concentration was remarkably similar regardless of whether or not the new particle formation events were observed (Lehtipalo et al., 2009).

At Mace Head the nano-CN concentrations varied between $10^{2}$ and $10^{4} \mathrm{~cm}^{-3}$ (Fig. 1b). During the day the overall concentration was lower by a factor of two at Mace Head than in Hyytiälä, and during the night almost one order of magnitude lower. Small clusters and particles are effectively lost by coagulational scavenging (Kerminen et al., 2001). The reason for higher nano-CN concentrations in Hyytiälä compared to Mace Head cannot, however, be explained solely by differences in the coagulation sink, as demonstrated by Fig. 2. It should be noted that we tend to underestimate the coagulation sink, especially in Mace Head, as the super-micron particles were not measured there and are thus missing from the calculated value of the CoagS. Nevertheless, the coagulation sink is generally lower in coastal conditions than in the forest (e.g. Dal Maso et al., 2002), and definitely not high enough to explain an order of magnitude difference in the concentrations. This leads to the conclusion that the production rate of nano- $\mathrm{CN}$ is higher in Hyytiälä.

Figure 3 presents a 4-day time series (13-16 June 2008) of total particle concentration in Mace Head between 1.5$3 \mathrm{~nm}$ and $3-5 \mathrm{~nm}$. The concentrations measured with the PH$\mathrm{CPC}$ and the NAIS agree very well in both size classes, especially for the negative corona charging side of the NAIS. The 3-5 nm particles are mostly associated with particle formation bursts, and were thus observed in high quantities at daytime low tides. The $1.5-3 \mathrm{~nm}$ particles, however, had no clear relation to the tidal cycle. Another type of divider was

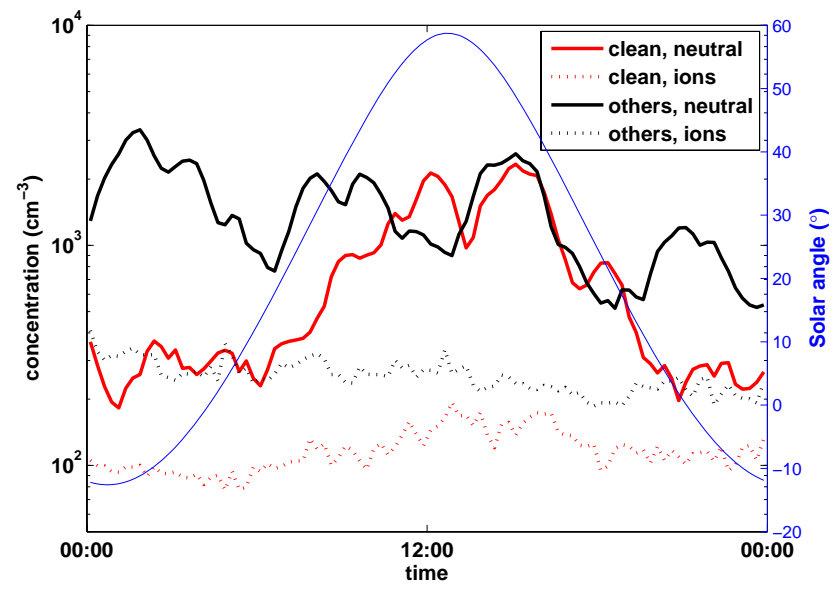

Fig. 4. Diurnal variation of nano-CN and $1.5-3 \mathrm{~nm}$ ions (pos+neg) in Mace Head. The data is divided into two fractions depending on whether the air mass trajectories came directly from the ocean (clean, red lines), or if they had passed over land areas (others, black lines). The blue line represents the calculated solar elevation angle in Mace Head during summer.

found: when the air mass trajectories originated directly from the ocean, i.e. from the clean sector without much of anthropogenic influence, the nano- $\mathrm{CN}$ concentration was stable and very low during the night, but started increasing soon after sunrise reaching a maximum at the same time as the solar elevation was highest (Fig. 4). These daytime maxima were not observed by the NAIS, indicating that the $\mathrm{CN}$ are very small and thus disguised by the charger ions in the NAIS. When the air mass advecting to the site had passed over land, no clear diurnal cycle could be distinguished. The nighttime values, in particular, were much higher than in the marine air masses. On a few days a nighttime maximum was observed, but they were not as strong or observed as frequently as in Hyytiälä. The ion cluster concentrations in the same size range were pretty stable throughout the day, but, as also pointed out by Vana et al. (2008), their concentration is much higher in air masses from the land sector, probably due to radon, which is one of the main sources of small ions (the other being cosmic radiation, which should be independent of the air mass origin).

The charged fraction in the size class $1.3-3 \mathrm{~nm}$ calculated from the ion spectrometer and PH-CPC measurements was on average about $1 \%$ in Hyytiälä and $18 \%$ in Mace Head. The maximum estimate of the ion-ion recombination products falling into the same size range accounted on average for only a few percent of neutral nano- $\mathrm{CN}$ in Hyytiälä, but more than half of the measured concentration in Mace Head. The diurnal variation of both the ion ratio and the recombination ratio (Fig. 5) showed a minimum in the evening for Hyytiälä and around midday in Mace Head. The ratios were a bit higher in Mace Head during clean, marine air masses. All in all, the contribution of ions varied 

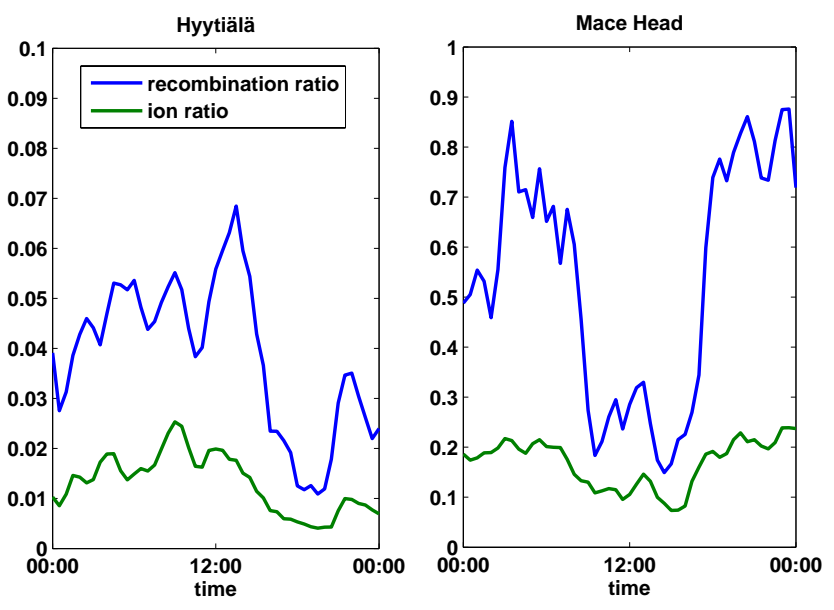

Fig. 5. Median fraction of ions from all measured particles in the size range $1.3-3 \mathrm{~nm}$ (ion ratio) and the fraction of recombination products from neutral nano- $\mathrm{CN}$ (recombination ratio).

a lot from day to day in both places, but it seems that the ions have a much bigger contribution to the nano-particle concentration in Mace Head than in Hyytiälä.

Table 1 summarizes the characteristics of the measured concentrations in Hyytiälä and Mace Head during the EUCAARI campaign in 2008.

\subsection{Particle formation}

At Mace Head, new particle formation usually occurs as strong bursts of nucleation mode particles during low tide (e.g. O'Dowd, 2002b; Vana et al., 2008). Figure 6 presents an example of the size distributions measured with the PHCPC and the NAIS with two distinct particle formation bursts occurring at 12:30 and 15:30 LT, while tidal minima were around 3:30 and 16:00. On the first particle burst most particles have grown to sizes over $3.5 \mathrm{~nm}$ before reaching our measurement location, and to sizes over $2 \mathrm{~nm}$ on the second burst. No increase can be seen in the smallest particles or ions prior to or during the particle burst. However, a rapid change in total number concentration challenges our measurement technique as the supersaturation decreases in the $\mathrm{PH}-\mathrm{CPC}$ due to vapor depletion and thus limits the reliability of measurements during intensive particle formation. This explains the dip in the sub- $2 \mathrm{~nm}$ particle concentration in $\mathrm{PH}-$ $\mathrm{CPC}$ data during the first particle burst. The background concentration of $>20 \mathrm{~nm}$ particles, as well as the concentration of small ions stayed stable throughout the day.

The formation rate of $1 \mathrm{~nm}$ particles during particle formation events in Mace Head has been estimated to be as high as $300-10000 \mathrm{~cm}^{-3} \mathrm{~s}^{-1}$, corresponding to cluster concentrations of $4 \times 10^{4}-7 \times 10^{6} \mathrm{~cm}^{-3}$ (Dal Maso et al., 2002). Clearly, the measured concentrations, both neutral and charged, are too low for explaining these kinds of particle bursts. In Hyytiälä, the observed formation rate of 2-
Table 1. Characteristics of nano-CN concentrations in Hyytiälä and Mace Head (MH). The recombination ratio is the maximum estimate of recombination products divided by the neutral nano- $\mathrm{CN}$. The ion ratio is the fraction of ions from all particles between 1.3$3 \mathrm{~nm}$.

\begin{tabular}{llll}
\hline & Hyytiälä & MH (all data) & MH (clean sector) \\
\hline Mean $\left(\mathrm{cm}^{-3}\right)$ & 8950 & 3490 & 1540 \\
Median $\left(\mathrm{cm}^{-3}\right)$ & 3380 & 890 & 570 \\
$5-95 \%\left(\mathrm{~cm}^{-3}\right)$, day & $440-29000$ & $150-12000$ & $180-10000$ \\
$5-95 \%\left(\mathrm{~cm}^{-3}\right)$, night & $150-46000$ & $30-11000$ & $30-3000$ \\
Recombination ratio & $3 \%$ & $54 \%$ & $62 \%$ \\
Ion ratio & $1 \%$ & $18 \%$ & $19 \%$ \\
\hline
\end{tabular}

$3 \mathrm{~nm}$ particles varies between $0.22-3.9 \mathrm{~cm}^{-3} \mathrm{~s}^{-1}$ (Manninen et al., 2009a), and the estimated neutral cluster concentration between $7000-50000 \mathrm{~cm}^{-3}$ (Kulmala et al., 2007a), which is close to the measured nano- $\mathrm{CN}$ values.

\section{Discussion and conclusions}

Both in Hyytiälä and Mace Head neutral nanometer-size CN were observed continuously with a pulse-height CPC, even when no particle formation was detected with traditional instrumentation, like the DMPS/SMPS with a cut-off size at $3 \mathrm{~nm}$. These clusters or molecules seemed to be more abundant in Hyytiälä, especially at nighttime, which could not be explained solely by differences in the coagulation sink. This, along with the differences in their diurnal variation, indicates that the sources of the nano-CN differ between Hyytiälä and Mace Head, at least in magnitude.

The composition of nanoparticles is hard to measure directly, and is therefore not known. Proposed candidates for forming clusters include oxidation products of volatile organic compounds (e.g. Bonn and Moortgat, 2003). For example, monoterpenes and their oxidation products exhibit a similar diurnal variation in Hyytiälä than the measured nanoCN (Rinne et al., 2005; Sellegri et al., 2005). The fact that the nano-CN concentration follows solar elevation in Mace Head when air masses come from the ocean implies that their formation includes some photochemical reactions. When the air masses have passed over land area, VOCs emitted from the vegetation or anthropogenic emissions might explain the higher and more varying concentrations. At least the nano$\mathrm{CN}$ seem to not consist of the same biogenic iodine compounds that make the nucleation mode particles, as the nano$\mathrm{CN}$ do not exhibit a similar tidal cycle as the particle formation events. The exact chemical composition of the nano-CN remains to be solved in future studies.

A much bigger fraction of the nano- $\mathrm{CN}$ can be explained solely by ions in Mace Head than in Hyytiälä. In marine air masses even all of the observed nano- $\mathrm{CN}$ at nighttime could be cluster ions and their recombination products. In Hyytiälä, 

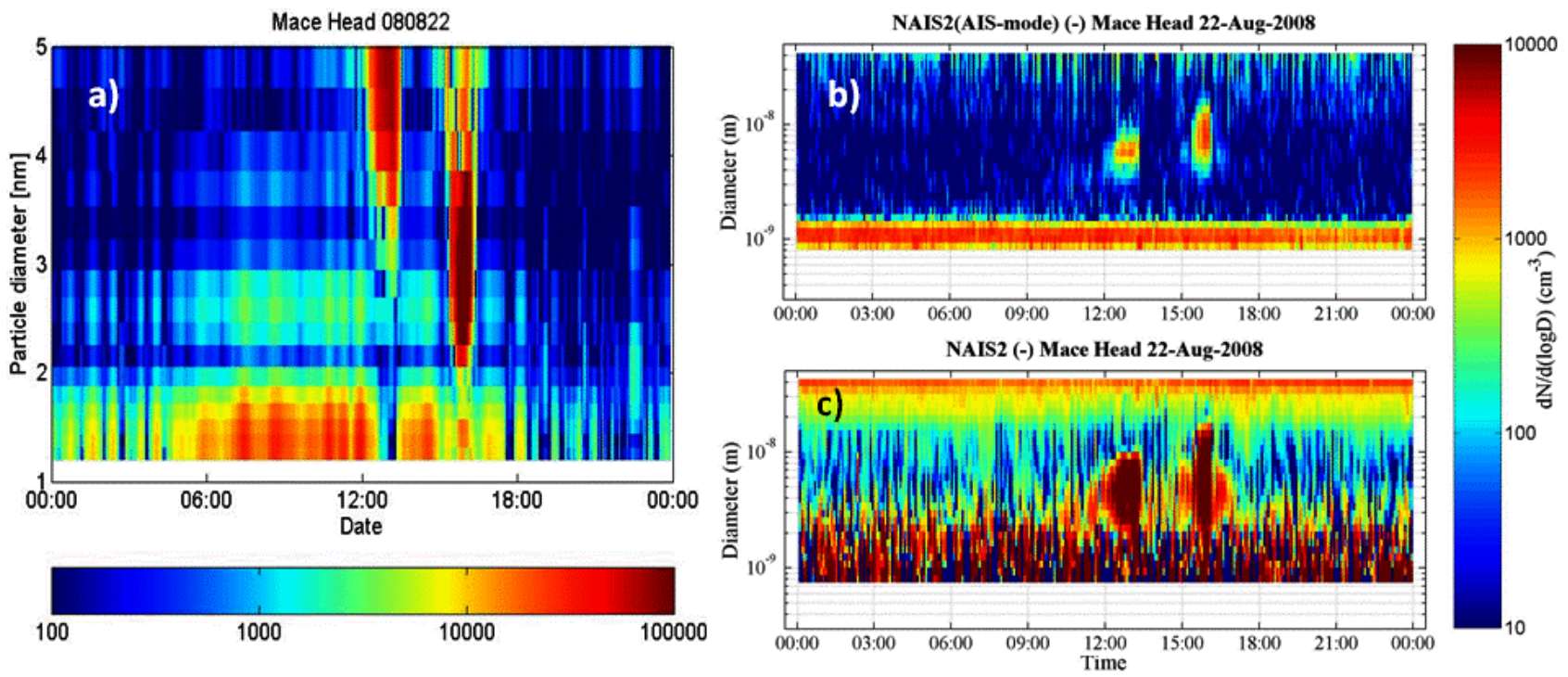

Fig. 6. Size distribution of 1.3-5 nm particles measured with the PH-CPC (a), 0.8-40 nm negative ions (b), and total particle distribution (c) measured with the NAIS in Mace Head 22 August 2008. Low tide occurred around 03:30 and 16:00.

the minimum in ion fraction at nighttime gives a reason to assume that we have a source of neutral nano-CN near the ground. One should, however, be careful when comparing the measurements with a CPC and an ion spectrometer, since the size is determined with different methods, which might lead to discrepancies in the smallest sizes.

It can be concluded that in Hyytiälä we have a constant resource of seed-embryos for new particle formation. The measured nano- $\mathrm{CN}$ concentrations are easily large enough to explain particle formation events via activation of clusters. The nano-CN concentration does not, however, seem to be the critical factor determining whether a nucleation event occurs. The main process limiting particle formation is probably the competition between growth of particles and their loss by scavenging, rather than the production of initial clusters (Riipinen et al., 2007). Maybe sulphuric acid, which is often connected to first steps of new particle formation (e.g. Weber et al., 1996; Sihto et al., 2006; Petäjä et al., 2009; Nieminen et al., 2009), or some other vapor is needed for activation and/or growth of particles. In Mace Head the concentrations of the nano- $\mathrm{CN}$ and the cluster ions, even together, are too small to account for the observed formation rate of the nucleation mode particles. Thus it seems that the particles are formed by homogenous nucleation of the same vapor(s), which make them grow to sizes of a few nanometers before reaching our measurement location.

The apparently different nucleation mechanisms behind the new particle formation at Mace Head and Hyytiälä suggest that also in other environments, where nucleation rate is high (over some tens in $\mathrm{cm}^{-3} \mathrm{~s}^{-1}$ ), new particle formation happens via homogeneous nucleation, and the activation type nucleation is probably dominating in places where the formation rate is of the order of unity.
Acknowledgements. This work has been partially funded by European Commission 6th Framework programme project EUCAARI, contract no. 036833-2 (EUCAARI) and Academy of Finland Center of Excellence program (project number 1118615). Maj and Tor Nessling foundation, and EPA Ireland are acknowledged for financial support. NOAA Air Resources Laboratory (ARL) is acknowledged for the provision of the HYSPLIT transport and dispersion model and READY website (http://www.arl.noaa.gov/ready.html). M. McGrath is acknowledged for proofreading the manuscript.

Edited by: A. Wiedensohler

\section{References}

Aalto, P., Hämeri, K., Becker, E., Weber, R., Salm, J., Mäkelä, J. M., Hoell, C., O’Dowd, C. D., Karlsson, H., Hansson, H.-C., Väkevä, M., Koponen, I. K., Buzorius, G., and Kulmala, M.: Physical characterization of aerosol particles in boreal forests, Tellus 53B, 344-358, 2001.

Asmi, E., Sipilä, M., Manninen, H. E., Vanhanen, J., Lehtipalo, K., Gagné, S., Neitola, K., Mirme, A., Mirme, S., Tamm, E., Uin, J., Komsaare, K., Attoui, M., and Kulmala, M.: Results of the first air ion spectrometer calibration and intercomparison workshop, Atmos. Chem. Phys., 9, 141-154, doi:10.5194/acp-9-141-2009, 2009.

Bonn, B. and Moortgat, G. K.: Sesquiterpene ozonolysis: origin of atmospheric new particle formation from biogenic hydrocarbons, Geophys. Res. Lett., 30, 1585, doi:10.1029/2003GL017000, 2003.

Dal Maso, M., Kulmala, M., Lehtinen, K. E. J., Mäkelä, J. M., Aalto, P., and O'Dowd, C. D.: Condensation and coagulation sinks and formation of nucleation mode particles in coastal and boreal forest boundary layers, J. Geophys. Res., 107, 8097, doi:10.1029/20000JD000213, 2002. 
Dal Maso, M., Kulmala, M., Riipinen, I., Wagner, R., Hussein, T., Aalto, P. P., and Lehtinen, K. E. J.: Formation and growth of fresh atmospheric aerosols: eight years of aerosol size distribution data from SMEAR II, Hyytiälä, Finland, Boreal Environ. Res., 10, 323-336, 2005.

Dick, W. D., McMurry, P. H., Weber, R. J., and Quant, R.: Whitelight detection for nanoparticle sizing with the TSI Ultrafine Condensation Particle Counter, J. Nanoparticle Res., 2, 85-90, 2000.

Draxler, R. R. and Rolph, G. D.: HYSPLIT (HYbrid Single-Particle Lagrangian Integrated Trajectory) Model access via NOAA ARL READY Website (http://www.arl.noaa.gov/ready/hysplit4.html), NOAA Air Resources Laboratory, Silver Spring, MD, 2003.

Gagné, S., Laakso, L., Petäjä, T., Kerminen, V.-M., and Kulmala, M.: Analysis of one year of Ion-DMPS data from the SMEAR II station, Finland, Tellus, 60B, 318-329, 2008.

Hari, P. and Kulmala, M.: Station for measuring ecosystematmosphere relations (SMEAR II), Boreal Environ. Res. 10, 315322, 2005.

Hirsikko, A., Laakso, L., Hõrrak, U., Aalto, P. P., Kerminen, V.M., and Kulmala, M.: Annual and size dependent variation of growth rates and ion concentrations in boreal forest, Boreal Environ. Res., 10, 357-369, 2005.

Hõrrak, U., Salm, J., and Tammet, H.: Bursts of intermediate ions in atmospheric air, J. Geophys. Res., 103, 13909-13915, 1998.

Hoffmann, T., O'Dowd, C. D., and Seinfeld, J. H.: Iodine oxide homogeneous nucleation: An explanation for coastal new particle production, Geophys. Res. Lett. 28, 1949-1952, 2001.

Iida, K., Stolzenburg, M., McMurry, P., Dunn, M. J., Smith, J. N., Eisele, F., and Keady, P.: Contribution of ion-induced nucleation to new particle formation: Methodology and its application to atmospheric observations in Boulder, Colorado, J. Geophys. Res., 111, D23201, doi:1029/2006JD007167, 2006.

IPCC: Summary for Policymakers, in: Climate Change 2007: The Physical Science Basis, Contribution of Working Group I to the Fourth Assessment Report of the Intergovernmental Panel on Climate Change, edited by: Solomon, S., Qin, D., Manning, M., Chen, Z., Marquis, M., Averyt, K. B., Tignor, M., and Miller, H. L., Cambridge University Press, Cambridge, United Kingdom and New York, NY, USA, 2007.

Jimenez, J. L., Bahreini, R., Cocker III, D. R., Zhuang, H., Varutbangkul, V., Flagan, R. C., Seinfeld, J. H., O'Dowd, C. D., and Hoffmann, T.: New particle formation from photooxidation of diiodomethane $\left(\mathrm{CH}_{2} \mathrm{I}_{2}\right)$, J. Geophys. Res., 108, 4318, doi:10.1029/2002JD002452, 2003.

Kerminen, V.-M., Pirjola, L., and Kulmala M.: How significantly does coagulational scavenging limit atmospheric particle production?, J. Geophys. Res., 106, 24119-24126, 2001.

Kulmala, M., Pirjola, L., and Mäkelä, J. M.: Stable sulphate clusters as a source of new atmospheric particles, Nature, 404, 66-69, 2000.

Kulmala, M., Vehkamäki, H., Petäjä, T., Dal Maso, M., Lauri, A., Kerminen, V.-M., Birmili, W., and McMurry, P. H.: Formation and growth rates of ultrafine atmospheric particles: a review of observations, J. Aerosol Sci., 35, 143-176, 2004.

Kulmala, M., Lehtinen, K. E. J., and Laaksonen, A.: Cluster activation theory as an explanation of the linear dependence between formation rate of $3 \mathrm{~nm}$ particles and sulphuric acid concentration, Atmos. Chem. Phys., 6, 787-793, doi:10.5194/acp-6-787-2006,
2006.

Kulmala, M., Riipinen, I., Sipilä, M., Manninen, H., Petäjä, T., Junninen H., Dal Maso, M., Mordas, G., Mirme, A., Vana, M., Hirsikko, A., Laakso, L., Harrison, R. M., Hanson, I., Leung, C., Lehtinen, K. E. J., and Kerminen, V.-M.: Towards direct measurement of atmospheric nucleation, Science, 318, 89-92, 2007a.

Kulmala, M., Mordas, G., Petäjä, T., Grönholm, T., Aalto, P. P., Vehkamäki, H., Hienola, A. I., Herrmann, E., Sipilä, M., Riipinen, I., Manninen, H. E., Hämeri, K., Stratmann, F., Bilde, M., Winkler, P. M., Birmili, W., and Wagner, P. E.: The condensation particle counter battery (CPCB): a new tool to investigate the activation properties of nanoparticles, J. Aerosol Sci., 38, 289-304, 2007b.

Kulmala, M., Asmi, A., Lappalainen, H. K., Carslaw, K. S., Pöschl, U., Baltensperger, U., Hov, Ø., Brenquier, J.-L., Pandis, S. N., Facchini, M. C., Hansson, H.-C., Wiedensohler, A., and O'Dowd, C. D.: Introduction: European Integrated Project on Aerosol Cloud Climate and Air Quality interactions (EUCAARI) - integrating aerosol research from nano to global scales, Atmos. Chem. Phys., 9, 2825-2841, doi:10.5194/acp-9-2825-2009, 2009.

Laakso, L., Anttila, T., Lehtinen, K. E. J., Aalto, P. P., Kulmala, M., Hõrrak, U., Paatero, J., Hanke, M., and Arnold, F.: Kinetic nucleation and ions in boreal forest particle formation events, Atmos. Chem. Phys., 4, 2353-2366, doi:10.5194/acp-4-2353-2004, 2004.

Laaksonen, A., Hamed, A., Joutsensaari, J., Hiltunen, L., Cavalli, F., Junkermann, W., Asmi, A., Fuzzi, S., and Facchini, M.-C.: Cloud condensation nucleus production from nucleation events at a highly polluted region, Geophys. Res. Lett., 32, L06812, doi:10.1029/2004GL022092, 2005.

Lehtipalo, K., Sipilä, M., Riipinen, I., Nieminen, T., and Kulmala, M.: Analysis of atmospheric neutral and charged molecular clusters in boreal forest using pulse-height CPC, Atmos. Chem. Phys., 9, 4177-4184, doi:10.5194/acp-9-4177-2009, 2009.

Manninen, H. E., Nieminen, T., Riipinen, I., Yli-Juuti, T., Gagné, S., Asmi, E., Aalto, P. P., Petäjä, T., Kerminen, V.-M., and Kulmala, M.: Charged and total particle formation and growth rates during EUCAARI 2007 campaign in Hyytiälä, Atmos. Chem. Phys., 9, 4077-4089, doi:10.5194/acp-9-4077-2009, 2009.

Manninen, H. E., Petäjä, T., Asmi, E., Riipinen, I., Nieminen, T., Mikkilä, J., Hõrrak, U., Mirme, A., Mirme, S., Laakso, L., Kerminen, V.-M., and Kulmala, M.: Long-term field measurements of charged and neutral clusters using Neutral cluster and Air Ion Spectrometer (NAIS), Boreal Environ. Res., 14, 591-605, 2009b.

Mirme, A., Tamm, E., Mordas, G., Vana, M., Uin, J., Mirme, S., Bernotas, T., Laakso, L., Hirsikko, A., and Kulmala, M.: A wide-range multi-channel Air Ions Spectrometer, Boreal Environ. Res., 12, 247-264, 2007.

Nieminen, T., Manninen, H., Sihto, S.-L., Yli-Juuti, T., Mauldin, R. L., Petäjä, T., Riipinen, I., Kerminen, V.-M., and Kulmala, M.: Connection of sulphuric acid to atmospheric nucleation in boreal forest, Environ. Sci. Technol., 43, 4715-4721, 2009.

O'Dowd, C. D.: Biogenic coastal aerosol production and its influence on aerosol radiative properties, J. Geophys. Res., 106, 1545-1549, 2001.

O’Dowd, C. D., Aalto, P, Hämeri, K., Kulmala, M, and Hoffmann, T.: Atmospheric particles from organic vapours, Nature, 416, 497-498, 2002a. 
O’Dowd, C. D., Hämeri, K., Mäkelä, J. M., Väkevä, M., Aalto, P. P., de Leeuw, G., Kunz, G., J., Becker, E., Hansson, H.-C., Allen, A. G., Harrison, R. M., Berresheim, H., Kleefeld, C., Geever, M., Jennings, S. G., and Kulmala, M.: Coastal new particle formation: Environmental conditions and aerosol physicochemical characteristics during nucleation bursts, J. Geophys. Res., 107(D19), 8107, doi:10.1029/2000JD000206, 2002b.

O’Dowd, C. D., Jimenez, J. L., Bahreini, R., Flagan, R. C., Seinfeld, J. H., Hämeri, K., Pirjola, L., Kulmala, M., Jennings, S. G., and Hoffmann, T.: Marine aerosol formation from biogenic iodine emissions, Nature, 417, 632-636, 2002c.

O'Dowd, C. D., Aalto, P. P., Yoon, Y. J., and Hämeri, K.: The use of the pulse height analyzer ultrafine condensation particle counter (PHA-UCPC) technique applied to sizing of nucleation mode particles of different chemical composition, J. Aerosol Sci., 35, 2, 205-216, 2004.

Petäjä, T., Mauldin III, R. L., Kosciuch, E., McGrath, J., Nieminen, T., Paasonen, P., Boy, M., Adamov, A., Kotiaho, T., and Kulmala, M.: Sulfuric acid and $\mathrm{OH}$ concentrations in a boreal forest site, Atmos. Chem. Phys., 9, 7435-7448, doi:10.5194/acp9-7435-2009, 2009.

Riipinen, I., Sihto, S.-L., Kulmala, M., Arnold, F., Dal Maso, M., Birmili, W., Saarnio, K., Teinilä, K., Kerminen, V.-M., Laaksonen, A., and Lehtinen, K. E. J.: Connections between atmospheric sulphuric acid and new particle formation during QUEST IIIIV campaigns in Heidelberg and Hyytiälä, Atmos. Chem. Phys., 7, 1899-1914, doi:10.5194/acp-7-1899-2007, 2007.

Rinne, J., Ruuskanen, T. M., Reissell, A., Taipale, R., Hakola, H., and Kulmala, M.: On-line PTR-MS measurements of atmospheric concentrations of volatile organic compounds in a European boreal forest ecosystem, Boreal Environ. Res., 10, 425-436, 2005.

Saros, M., Weber, R. J., Marti, J., and McMurry, P. H.: Ultra fine aerosol measurement using a condensation nucleus counter with pulse height analysis, Aerosol Sci. Technol., 25, 200-213, 1996.

Sellegri, K., Hanke, M., Umann, B., Arnold, F., and Kulmala, M.: Measurements of organic gases during aerosol formation events in the boreal forest atmosphere during QUEST, Atmos. Chem. Phys., 5, 373-384, doi:10.5194/acp-5-373-2005, 2005.

Sihto, S.-L., Kulmala, M., Kerminen, V.-M., Dal Maso, M., Petäjä, T., Riipinen, I., Korhonen, H., Arnold, F., Janson, R., Boy, M., Laaksonen, A., and Lehtinen, K. E. J.: Atmospheric sulphuric acid and aerosol formation: implications from atmospheric measurements for nucleation and early growth mechanisms, Atmos. Chem. Phys., 6, 4079-4091, doi:10.5194/acp-6-4079-2006, 2006.

Sipilä, M., Lehtipalo, K., Kulmala, M., Petäjä, T., Junninen, H., Aalto, P. P., Manninen, H. E., Kyrö, E.-M., Asmi, E., Riipinen, I., Curtius, J., Kürten, A., Borrmann, S., and O’Dowd, C. D.: Applicability of condensation particle counters to measure atmospheric clusters, Atmos. Chem. Phys., 8, 4049-4060, doi:10.5194/acp-8-4049-2008, 2008.
Sipilä, M., Lehtipalo, K., Attoui, M., Neitola, K., Petäjä, T., Aalto, P. P., O'Dowd, C. D., and Kulmala, M.: Laboratory verification of PH-CPC's ability to monitor atmospheric sub- $3 \mathrm{~nm}$ clusters, Aerosol Sci. Technol., 43, 2, 126-135, 2009.

Spracklen, D. V., Carslaw, K. S., Kulmala, M., Kerminen, V.-M., Mann, G. W., and Sihto, S.-L.: The contribution of boundary layer nucleation events to total particle concentrations on regional and global scales, Atmos. Chem. Phys., 6, 5631-5648, doi:10.5194/acp-6-5631-2006, 2006.

Tammet, H. and Kulmala, M.: Simulation tool for atmospheric aerosol nucleation bursts, J. Aerosol Sci., 36, 173-196, 2005.

Tammet, H.: Continuous scanning of the mobility and size distribution of charged clusters and nanometer particles in atmospheric air and the balanced scanning mobility analyzer BSMA, Atmos. Res., 82, 523-535, 2006.

Turco, R. P., Zhao, J. X., and Yu, F.: A new source of tropospheric aerosols: Ion-ion recombination, Geophys. Res. Lett., 25, 635638, 1998.

Vana, M., Ehn, M., Petäjä, T., Vuollekoski, H., Aalto, P., de Leeuw, G., Ceburnis, D., O'Dowd, C. D., and Kulmala, M.: Characteristic features of air ions at Mace Head on the west coast of Ireland, Atmos. Res., 90, 278-286, 2008.

Winkler, P. M., Steiner, G., Vrtala, A., Vehkamäki, H., Noppel, M., Lehtinen, K. E. J., Reischl, G. P., Wagner, P. E., and Kulmala, M.: Heterogeneous nucleation experiments bridging scale from molecular ion clusters to nanoparticles, Science, 319, 13741377, 2008.

Weber, R. J., McMurry, P. H., Eisele, F. L., and Tanner, D. J.: Measurement of expected nucleation precursor species and 3-500-nm diameter particles at Mauna Loa observatory, Hawaii, J. Atmos. Sci., 52, 2242-2257, 1995.

Weber, R. J., Marti, J., McMurry, P. H., Eisele, F., Tanner, D. J., and Jefferson, A.: Measured atmospheric new particle formation rates: implications for nucleation mechanisms, Chem. Eng. Comm., 151, 53-64, 1996.

Yoon, Y. J., O'Dowd C. D., Jennings, S. G., and Lee, S. H.: Statistical characteristics and predictability of particle formation events at Mace Head, J. Geophys. Res., 111, D13204, doi:10.1029/2005JD006284, 2006.

Yu, F. and Turco, R. P.: Ultrafine aerosol formation via ionmediated nucleation, Geophys. Res. Lett., 27, 883-886, 2000.

Yu, F. and Turco, R.: Case studies of particle formation events observed in boreal forests: implications for nucleation mechanisms, Atmos. Chem. Phys., 8, 6085-6102, doi:10.5194/acp-86085-2008, 2008.

Yu, F., Wang, Z., Luo, G., and Turco, R.: Ion-mediated nucleation as an important global source of tropospheric aerosols, Atmos. Chem. Phys., 8, 2537-2554, doi:10.5194/acp-8-2537-2008, 2008. 